\title{
Community College Mentoring: Minority Student Perception
}

\author{
Myron L. Pope
}

The ethnic and cultural landscape of the American community college is becoming increasingly diverse. The U. S. Census Bureau reported that $42.3 \%$ of African Americans in higher education are in the community college system, along with $50 \%$ of the Native American and $55.6 \%$ of Hispanic enrollment (NCES, 1999). Despite these changes, these populations of students may be confronted with many issues that are detrimental to their retention and success, such as lower levels of academic preparation in high school, lower socioeconomic status, and greater alienation in these institutions (Tinto, 1975; Astin, 1982; Jalomo, 2000). All of these factors contribute significantly to their high dropout rates and poor academic achievement. The success of these students depends, in many cases, on their integration into the college environment. One of the more common efforts at community colleges to achieve such integration is through the mentoring program.

The mentoring process has been perceived traditionally as a model for apprenticeships in graduate education, but it is now increasingly identified as a retention strategy for undergraduate education (Jacobi, 1991). This strategy has been demonstrated through both formal and informal methods. Formal mentoring programs have provided the most significant increase in enrollment and retention of minority students, as well as increased their overall satisfaction with their educational experience (James, 1991). Mentoring programs in these formal settings have focused traditionally on work-based learning as opposed to the career development and fulfillment of the psychosocial needs of the students (Ensher, 1997; Stromei, 1998). This process affords students opportunities to create a bond with the institution through programs that facilitate academic and 
social integration. However, for many minority students in the community college, the time, energy, and ability necessary to participate in such well-designed programs are limited due to the many responsibilities and barriers that put them at risk, such as family, work, lack of support, and lack of transportation (Beatty-Guenther, 1994). Thus, institutions have to provide alternatives to meet the challenges of these students' complex lives.

Some institutions have developed alternative programs that assist minority students who have conflicts in connecting with mentors in order to achieve the career-related and psychosocial guidance needed to survive and be successful in college. Stromei (2000) emphasizes how the Arranged Mentor for Instructional Guidance and organizational Support (AMIGOS ${ }^{\mathrm{TM}}$ ) program, which is currently used by many organizations and educational institutions nationwide, has been successful in matching mentors and protégés based on personality types. The AMIGOS ${ }^{\mathrm{TM}}$ model highlighted the necessity of the student working with the mentor during the student's transition into the institution by participating in problem-solving activities, training sessions, and social activities. Another successful program at Prince George's Community College focuses on establishing and maintaining constructive relationships with students who are African American, Hispanic, Native American, and Asian (James, 1991). The mentors for the program are full-time and part-time faculty, staff, and administrators who are trained to provide supportive classroom environments and proper support services to these students. The ultimate success of any of these types of programs lies in the ability of community colleges to assist the student in dealing with the everyday challenges faced by minority students.

Considering that most of the research regarding mentoring focuses on specific programs (James, 1991; Beatty-Guenther, 1994; Stromei, 2000), it is important to assess the effectiveness of the various levels of mentoring for minority students. These studies focus on the effect and perceptions of specific programs on the educational experiences of these students. However, such programs do not exist at all colleges, and thus, the opportunity for minority students to adapt to and be successful in the community college environment through this effective strategy does not always exist. Additionally, existing research does not include the perceptions of minority students regarding the significance of multiple levels of 
mentoring to their success. The present investigation proposes that multiple levels of mentoring provide both formal and informal methods of mentoring for minority students. Formal methods include all of the aforementioned programming that community colleges conduct to enhance student success, and informal methods include faculty accessibility and support and the presence of minority faculty and staff members on the campus. The latter method is not something that institutions plan specifically but is one that could potentially have an effect on minority student success. This present study will analyze the perceptions of minority students regarding this notion of multiple levels of mentoring on their community college campuses. More specifically, this research will address the following questions:

1. What aspects of mentoring are important to minority students?

2. What are minority students' perceptions of whether their current institution provides these multiple levels of mentoring?

3. Is there a relationship between the perceptions of importance and the availability of these multiple levels of mentoring by minority students?

4. Is there a difference in minority students' perceptions, based upon race, of whether their current institution provides multiple levels of mentoring?

\section{Methodology}

This study was part of a larger investigation that involved 375 minority students enrolled at 15 community colleges around the country. The survey focused primarily on minority student perceptions of campus climate, institutional diversity, mentoring, and administrative support of diversity. Most sections of the survey, including the mentoring section discussed in this study, consisted of two-part questions. The first portion of the question required the students to respond to whether or not they perceived the statement to be important by answering yes or no. The second part of the question required the students to rate the statement on a Likert scale, with 1 indicating the lowest rating and 5 indicating the highest rating, based on their level of agreement with the listed statement. There were eight questions related to mentoring included in the questionnaire. After the questionnaire was drafted, it was presented to five stu- 
dent personnel administrators at five two-year institutions for review prior to its distribution for this study. Changes were made to the structure of the instrument based upon their recommendations.

The researcher selected the public two-year institutions randomly from the 2000 Carnegie Foundation classification of higher education institutions (Carnegie Foundation for the Advancement of Teaching, 2001). Twenty-five institutions were selected for this study, based on five regions of the country-Northeast, South, Midwest, Northwest, and West. Five institutions from each of these regions were selected using a stratified random sampling method from a list developed by the researcher.

After the institutions were selected, the names and addresses of the chief student affairs officers (CSAO), defined typically as vice president or dean of student services, of each of these institutions were located on each institution's Web site. These individuals were sent an e-mail message explaining the context of and requesting their participation in the study. They were asked to respond to (1) whether their institution would be willing to participate in the study; (2) whether they were willing to participate and who would be responsible for the distribution of the study to 25 students of color; and (3) when would be the most opportune time for the institution to participate in the study. There were 19 responses, with 15 of those individuals electing to participate in the study at various times between the middle of December 2001 and February 15, 2002. Based upon this response, there were ultimately five institutions from the South, five from the Midwest, three from the Northeast, and two institutions from the West that participated in the study.

The instruments were sent to the representative identified by the CSAO in December 2001. A letter was sent with the 25 instruments informing these individuals to whom (community college students of African American, Asian, Hispanic, and Native-American descent) and how (randomly selected individuals within these groups) to distribute the instrument. An envelope was attached to each of the questionnaires so that respondents could return their instruments confidentially to the representative. The representatives collected the sealed envelopes containing the questionnaires and returned them collectively to the researcher in a preaddressed envelope. The researcher distributed 375 instruments to these individuals, $250(66.67 \%)$ of which were returned and usable. 


\section{Results}

Of the 250 students of color to respond to the survey, female respondents accounted for $55.2 \%(\mathrm{~N}=138)$ of the respondents. Ethnically, 12 (4.8\%) of the respondents identified themselves as of Asian descent, 28 (11.2\%) identified themselves as Hispanic, 174 (69.6\%) identified themselves as African American, $22(8.8 \%)$ identified themselves as Native American, and 14 (5.6\%) identified themselves as multiracial. These numbers were not reflective of the actual percentages of these populations enrolled in community colleges because institutions that participated had certain minority groups that were more prevalent. The ages of the participants range from 18 to 52 , with an average age of 26.8 .

To answer the first research question, each student was asked to respond with either yes or no to a statement regarding whether or not they perceived each of the statements related to various aspects and types of mentoring as important to them. Based on the results, students of color felt that multiple types of mentoring are important for minority students attending community colleges. The respondents were positive overall in their perceptions of the mentoring statements, with at least $70 \%$ of the respondents stating that each type of mentoring was important in all except one of the statements. The statement, which received the least number of affirmative responses, $172(68.8 \%)$, was focused on whether the student thought that his or her individual participation in mentoring was important.

Additionally, most of the responses to the importance of mentoring based on individual ethnic groups were rated affirmatively by at least $70 \%$ of the respondents, with the exception of four overall instances. Only $8(66.7 \%)$ students of Asian descent rated the statement related to their peers serving as mentors to them as being important. Similarly, only 18 (64.3\%) Hispanics and 120 (69.0\%) African Americans responded affirmatively to this statement. Asian-American students also rated the statement related to staff members mentoring students relatively low with only one half of the respondents responding positively.

Research question two, which centered on minority students' perceptions of their current institution's provision of multiple levels of mentoring, asked participants to rate their level of agreement with their current institution's provision of each type of mentoring. The students responded to these by utilizing a 1-5 Likert scale, with 1 indicating that the students 
Affirmative Responses of Minority Students by Race Regarding the Importance of Mentoring

$\begin{array}{ccccc}\begin{array}{c}\text { African } \\ \text { American }\end{array} & \text { Asian } & \text { Hispanic } & \begin{array}{c}\text { Native } \\ \text { American }\end{array} & \begin{array}{c}\text { Multiethnic } \\ \mathbf{N}=14\end{array} \\ \mathbf{N}=\mathbf{1 7 8} & \mathbf{N} & \mathbf{N}=\mathbf{2 8} & \mathbf{N}=\mathbf{2 2} & \mathbf{N} \\ \mathbf{N} & \mathbf{N} & \mathbf{N} & \mathbf{N} & \mathbf{N} \\ (\%) & (\%) & (\%) & (\%) & (\%)\end{array}$

There are persons of color in administrative from whom I would

$\begin{array}{cccc}130 & 10 & 24 & 20 \\ (74.7 \%) & (83.3 \%) & (85.7 \%) & (90.9 \%)\end{array}$

12 seek mentoring at this institution.

There are persons of color in faculty roles from whom I would seek mentoring at this institution.

There are peer mentors who can advise me.

(69.0\%) 8 10 $(75.9 \%)$ (83.3\%) 22 22

The institution supports student-tofaculty interaction.

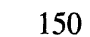

(86.2\%)

10
$(83.3 \%)$

\section{6}

(92.9\%)

14

$(100.0 \%)$

Faculty serve as mentors for all students.

$\begin{array}{ccccc}138 & 12 & 26 & 20 & 10 \\ (79.3 \%) & (100.0 \%) & (92.9 \%) & (90.9 \%) & (82.4 \%)\end{array}$

Staff members mentor students.

6 22 20 $\begin{array}{llll}(79.3 \%) & (50.0 \%) & (78.6 \%) & (90.9 \%)\end{array}$

I mentor other students.

$(64.4 \%)$

(66.7\%)

(71.4\%)

(81.8\%) $(100.0 \%)$

Mentoring is important for success at this institution.

$\begin{array}{ccccc}138 & 12 & 26 & 20 & 14 \\ (79.3 \%) & (100.0 \%) & (92.9 \%) & (90.9 \%) & (100.0 \%)\end{array}$

did not agree with the existence of such mentoring on their campus at all and 5 indicating that they strongly agreed with the statement that that type of mentoring existed on their campuses. 
The overall mean for all students participating in the study yielded means that ranged from the low of $3.22(\mathrm{SD}=1.23)$, the statement related to the individual student mentoring other students, to the high of $4.10(\mathrm{SD}=.88)$, the statement related to the importance of mentoring to student success at the institution.

Table 2

Minority Student Perception of Mentoring at Their Institution by Race $(N=250)$

\begin{tabular}{|c|c|c|c|c|c|}
\hline & $\begin{array}{c}\text { African } \\
\text { American } \\
\text { N }=178 \\
M \\
\text { SD) }\end{array}$ & $\begin{array}{c}\text { Asian } \\
\mathrm{N}=12 \\
\mathrm{M} \\
(\mathrm{SD})\end{array}$ & $\begin{array}{c}\text { Hispanic } \\
\mathrm{N}=\mathbf{2 8} \\
\mathrm{M} \\
(\mathrm{SD})\end{array}$ & $\begin{array}{c}\text { Native } \\
\text { American } \\
\mathrm{N}=22 \\
\mathrm{M} \\
\text { (SD) }\end{array}$ & $\begin{array}{c}\text { Multiethnic } \\
\text { N }=14 \\
\mathbf{M} \\
\text { (SD) }\end{array}$ \\
\hline $\begin{array}{l}\text { There are persons of } \\
\text { color in } \\
\text { administrative roles } \\
\text { from whom I would } \\
\text { seek mentoring at } \\
\text { this institution. }\end{array}$ & $\begin{array}{c}3.76 \\
(1.10)\end{array}$ & $\begin{array}{c}3.50 \\
(1.31)\end{array}$ & $\begin{array}{c}3.14 \\
(1.08)\end{array}$ & $\begin{array}{l}4.09 \\
(.68)\end{array}$ & $\begin{array}{l}4.14 \\
(.66)\end{array}$ \\
\hline $\begin{array}{l}\text { There are persons of } \\
\text { color in faculty roles } \\
\text { from whom I would } \\
\text { seek mentoring at } \\
\text { this institution. }\end{array}$ & $\begin{array}{c}3.78 \\
(1.10)\end{array}$ & $\begin{array}{c}4.00 \\
(1.48)\end{array}$ & $\begin{array}{c}3.50 \\
(1.13)\end{array}$ & $\begin{array}{l}4.00 \\
(.62)\end{array}$ & $\begin{array}{l}4.14 \\
(.60)\end{array}$ \\
\hline $\begin{array}{l}\text { There are peer } \\
\text { mentors who can } \\
\text { advise me. }\end{array}$ & $\begin{array}{c}3.48 \\
(1.11)\end{array}$ & $\begin{array}{c}2.17 \\
(1.40)\end{array}$ & $\begin{array}{c}3.14 \\
(1.20)\end{array}$ & $\begin{array}{l}3.91 \\
(.68)\end{array}$ & $\begin{array}{c}3.26 \\
(1.5)\end{array}$ \\
\hline $\begin{array}{l}\text { The institution } \\
\text { supports studert-to- } \\
\text { faculty interaction. }\end{array}$ & $\begin{array}{c}3.71 \\
(1.03)\end{array}$ & $\begin{array}{c}3.67 \\
(1.15)\end{array}$ & $\begin{array}{l}3.92 \\
(.90)\end{array}$ & $\begin{array}{l}4.00 \\
(.62)\end{array}$ & $\begin{array}{l}4.14 \\
(.36)\end{array}$ \\
\hline $\begin{array}{l}\text { Faculy serve as } \\
\text { mentors for all } \\
\text { students. }\end{array}$ & $\begin{array}{c}3.72 \\
(1.01)\end{array}$ & $\begin{array}{l}3.33 \\
(.99)\end{array}$ & $\begin{array}{c}3.57 \\
(1.37)\end{array}$ & $\begin{array}{l}3.55 \\
(.91)\end{array}$ & $\begin{array}{l}3.86 \\
(.66)\end{array}$ \\
\hline $\begin{array}{l}\text { Staff members } \\
\text { mentor students. }\end{array}$ & $\begin{array}{l}3.68 \\
(.92)\end{array}$ & $\begin{array}{c}2.83 \\
(1.64)\end{array}$ & $\begin{array}{c}3.57 \\
(1.37)\end{array}$ & $\begin{array}{l}3.73 \\
(.77)\end{array}$ & $\begin{array}{l}3.71 \\
(.73)\end{array}$ \\
\hline $\begin{array}{l}\text { I mentor other } \\
\text { students. }\end{array}$ & $\begin{array}{c}3.30 \\
(1.25)\end{array}$ & $\begin{array}{c}2.00 \\
(1.21)\end{array}$ & $\begin{array}{c}3.00 \\
(1.09)\end{array}$ & $\begin{array}{c}3.46 \\
(1.10)\end{array}$ & $\begin{array}{c}3.29 \\
(1.07)\end{array}$ \\
\hline $\begin{array}{l}\text { Mentoring is } \\
\text { important for } \\
\text { success at this } \\
\text { institution. }\end{array}$ & $\begin{array}{l}4.13 \\
(.84)\end{array}$ & $\begin{array}{l}4.17 \\
(.94)\end{array}$ & $\begin{array}{l}4.07 \\
(.81)\end{array}$ & $\begin{array}{l}4.09 \\
(.92)\end{array}$ & $\begin{array}{c}3.86 \\
(1.29)\end{array}$ \\
\hline
\end{tabular}


Among groups, there were marginal means also, with the lowest rated by Asian respondents for the statement related to the respondent mentoring other students $(\mathrm{M}=2.00 ; \mathrm{SD}=1.21)$, and the highest rated by Asian respondents for the statement related to the importance of mentoring for student success $(M=4.167 ; S D=.94)$. The researcher aggregated the means for each of the statements by race (see Table 2), and the overall perception of the availability of mentoring programs for Asian students was lower than the four other groups.

Research question number three, which related to whether a relationship existed between the perceptions of importance and availability of these multiple levels of mentoring by minority students, was answered by performing a chi-square analysis of the responses; both related to the students' perceptions of importance and the availability of the programs at their institutions. The results of this analysis indicated that there was an association between these two variables for each of the statements except one-faculty serve as mentors for all students (Table 3 ). Thus, the students perceived that the services they deemed important were services that were available on their campuses, with the exception of faculty mentoring students.

To answer research question number four, which focused on whether there was a difference in minority students' perceptions, based upon race, of their current institution's provision of multiple levels of mentoring, a one-way ANOVA was performed using race as the independent variable; the responses related to the availability of the types of mentoring as the dependent variable. Results indicated that there were significant differences in four of the statements regarding mentoring (Table 4). A multiple comparisons analysis was utilized to determine where those differences existed within the race variable. Hispanic respondents had a significantly lower agreement than did African-American, Native-American, and multiethnic students with the perceived availability of persons of color at their institution that they would consider as potential mentors. Similarly, Asian respondents had a significantly lower agreement level than did African-American and Native-American students regarding the availability of peer mentors to assist them. Also, Asian students had a significantly lower level of agreement than did African-American students with the statement regarding involvement of staff at their institution in the mentoring process. Finally, Asian students had a significantly 
lower level of agreement than did African-American and Native-American students regarding their individual participation in mentoring fellow students.

\section{Table 3}

\section{Minority Student Perception of the Relationship between the Importance and Availability of Mentoring Services}

Pearson Chi-Square

Value Significance

There are persons of color in administrative roles from whom I $.000^{*}$

would seek mentoring at this institution.

There are persons of color in faculty roles from whom I would seek mentoring at this institution.

There are peer mentors who can advise me.

The institution supports student-to-faculty

interaction.

Faculty serve as mentors for all students.

Staff members mentor students.

I mentor other students.

Mentoring is important for success at this

institution.

* The significance level in these cases is less than .0005 and not 0 .

\section{Discussion}

These findings suggest that mentoring is an important issue for minority students in community colleges around the country. The perceptions of these students regarding the aspects of mentoring that are impor- 
tant and the availability of these types of mentoring on their campuses should indicate to professionals the areas that are most significant in developing mentoring programs. From the results of the study, a conclusion, consistent with that in existing research, suggests that establishing multilevels of mentoring programs is important in providing success mechanisms for minority students.

\section{Table 4}

Summary of Analysis of Variance on Availability Response by Race

\begin{tabular}{|c|c|c|c|c|c|}
\hline Mentoring & df & SS & MS & $\mathbf{F}$ & Sig. \\
\hline \multicolumn{6}{|l|}{$\begin{array}{l}\text { There are persons of } \\
\text { color in } \\
\text { administrative roles } \\
\text { from whom I would } \\
\text { seek mentoring at } \\
\text { this institution. }\end{array}$} \\
\hline Between groups & 4 & 15.681 & 3.920 & 3.508 & $.008 *$ \\
\hline Within groups & 245 & 273.823 & 1.118 & & \\
\hline Total & 249 & 289.504 & & & \\
\hline
\end{tabular}

There are peer mentors who can advise me.

$\begin{array}{lrrrrr}\text { Between groups } & 4 & 27.165 & 6.791 & 5.245 & .000^{*} \\ \text { Within groups } & 245 & 317.219 & 1.295 & & \\ \text { Total } & 249 & 344.384 & & & \\ \text { entor other } & & & & & \\ \text { dents. } & 4 & 21.565 & 5.391 & 3.702 & .006^{*} \\ \text { Between groups } & & & & \\ \text { Within groups } & 245 & 356.771 & 1.456 & & \\ \text { Total } & 249 & 378.336 & & & \end{array}$

$* \mathrm{p}<.05$ 
The respondents in this study rated each type of mentoring relatively high, with a significant majority of the students providing positive responses regarding each type of mentoring. Each type was found in some form or combination of mentoring types in a variety of programs, activities, and environmental factors that the research has shown are important in mentoring relationships (Beatty-Guenter, 1994; James, 1991; Stromei, 2000). Much of this research promotes the theory that these types of programs are conducive to the transition, retention, and success of minority students in higher education.

Even though institutions are conducting a variety of mentoring programs for minority students, students in this study seemed to feel that these programs are only offered marginally. This perception is especially the case with Asian students who overall considered mentoring on their campuses to be less available than did students from other minority groups. The responses of these students may be indicative of the perception that students of Asian descent are "always successful" in higher education because of their overall higher success rates in terms of matriculation, retention, and graduation. This perception further suggests that Asian students do not need the special attention that students from other minority ethnic backgrounds may need (Monroe, Motoike, \& Nagda, 2002). This issue is reiterated further in the analysis of the perceptions of the availability of programs based upon the ethnic background of the students. Students of Asian descent, in more instances than any other race, again indicated that they did not particularly believe that certain types of mentoring were available on their campuses.

The research demonstrated that there was an association between the minority student's perception of the importance of the types of mentoring and the availability of those programs on their campuses. Even though this analysis did not break this relationship down by individual ethnic groups, the results of this study seem to indicate that there is evidence of these types of mentoring on their campuses, in which they may or may not be involved. Regardless of this involvement, which may be limited due to the unique set of characteristics of the community college student, minority students reported that these programs were available for the most part consistent with their perceptions of importance. 


\section{Limitations}

There were some threats to validity of this study due to the nature of its distribution. First, the study was not controlled for institutional size and resources, which may be factors in administrators' decisions to provide mentoring services and programs. Additionally, the study was not controlled geographically. As some sets of the ethnic groups included in this study are more populous in certain parts of the country, institutional leaders who work with these groups may want to focus more on these students in providing target services to enhance their success. Finally, the study did not control for individual student characteristics, such as a student who is only taking one course at this institution and has not had any connection with student services and programs versus a student who is enrolled to complete an entire program at this institution and has been exposed to a more formal orientation to these opportunities.

\section{Conclusion}

The projections of the potential increase in the number of minority students expected to enroll in community colleges over the next two decades, in conjunction with their past and present lack of success, provides an impetus for administrators to develop programs and services that will enhance the opportunities for these students to succeed. Success ultimately depends upon these students successfully becoming a part of the academic and social fabric of the institution. Formal mentoring programs have promoted this process in the past through recruitment, retention, and graduation of these students. However, community college leaders cannot limit their efforts to these formal programs. They must also implement informal multiple levels of mentoring for these students. In doing so, they cannot neglect any group due to their apparent lack of need for these types of services, especially Asian Americans because of their past overall academic success.

The programs must include a variety of factors, as identified by the respondents to this study. By way of multiple-level mentoring, minority students are exposed to a variety of individuals who are committed to ensuring that they adjust to life as a college student. These individuals will be able to assist these students in overcoming some of the precollege characteristics, such as their academic preparation and first-generation college student status, along with dealing with some of the conflicts that 
arise as a result of their enrollment in college, such as balancing their responsibilities. Additionally, research has demonstrated that students who participate in such programs are much more satisfied with their college experience than those who did not participate in mentoring programs (Fleming, 1984; Hughes, 1987; Woolbright, 1989; Lavant, Anderson, \& Tiggs, 1997). This finding is of particular importance to those who intend to replicate these studies.

Mentoring programs also cannot be one dimensional, in that the mentor must provide guidance to the student in academic, personal, and professional areas. The setting must incorporate an opportunity for these mentors to learn about students from various ethnic backgrounds. By making these individuals more conscious of the needs and concerns of these students, their opportunities to develop more comforting campus climates for community college students is enhanced. Since this approach would stress multiple levels of mentoring, administration, faculty, and fellow students will gain a greater appreciation of these students.

To enhance these opportunities further, community college leaders must begin more aggressively to recruit future faculty and administrators with these ethnic backgrounds. Minority students feel more comfortable approaching someone who "looks like me," and hiring people of the same ethnic background would demonstrate to students the commitment of community colleges to promoting their success.

The opportunities to enhance minority student success are potentially exponential as administrators analyze the possible strengths of multiple levels of mentoring. Mentoring systems will incorporate the entire campus culture in the process as opposed to centering on programs that focus on a minute aspect of students' lives and minimal numbers of students. Additionally, by establishing long-term plans to address each of the multiple levels of mentoring, administrators will be able to provide a campus climate conducive to the success of minority students, with individuals from all levels of the campus promoting the process.

\section{References}

Astin, A. (1982). Minorities in American higher education: Recent trends, current prospects, and recommendations. San Francisco: Jossey-Bass. 
Beatty-Guenter, P. (1994). Sorting, supporting, connecting, and transforming: Retention strategies at community colleges. Community College Journal of Research and Practice, 18 (2), 113-129.

Carnegie Foundation for the Advancement of Teaching. (2001). The Carnegie Classification of Institutions of Higher Education, 2000 Edition. Menlo Park, CA: Carnegie Foundation for the Advancement of Teaching.

Ensher, E. A. (1997). The effects of social exchanges on diverse mentoring relationships and career outcomes. Unpublished doctoral dissertation, Claremont Graduate University.

Fleming, J. (1984). Blacks in college: A comparative study of students' success in black and in white institutions. San Francisco: Jossey-Bass.

Hughes, M. (1987). Blacks students' participation in higher education. Journal of College Student Personnel, 28, 532.

Jacobi, M. (1991). Mentoring and undergraduate academic success: A literature review. Review of Educational Research, 61 (4), 505-532.

Jalomo, R. (2000). Assessing minority student performance. In S. R. Aragon (Ed.). Beyond access: Methods and models for increasing retention and learning among minority students, (pp.7-18). New Directions for Community Colleges, No.

112. San Francisco: Jossey Bass.

James, D. P. (1991). Minority student retention: The Prince George's Community College Program. In D. Angel and A. Barrera (Eds.), Rekindling minority enrollment, (pp. 57-62). New Directions for Community College, No. 74. San Francisco: Jossey-Bass.

Lavant, B. D., Anderson, J. L., \& Tiggs, J. W. (1997). Retaining African American men through mentoring initiatives. In M. J. Cuyjet (Ed.), Helping African American men succeed in college, (pp. 43-54). New Directions for Student Services, No. 80. San Francisco: Jossey-Bass.

Monroe, A., Motoike, P., \& Nagda, B. (2002, May 29-June 2). The "real" minority meets the "model" minority: A Black-Asian dialogue across, color, class, and religion. Paper presented at the $15^{\text {th }}$ Annual Conference on Race \& Ethnicity in American Higher Education, New Orleans, LA.

National Center for Education Statistics. (1999). Digest of education statistics 1999. (NCES 99-036). Washington, DC: U.S. Department of Education.

Stromei, L. K. (1998). An evaluation of a formal mentoring program for managers and the determinants for protégé satisfaction. Unpublished doctoral dissertation, University of New Mexico. 
Stromei, L. K. (2000). Increasing retention and success through mentoring. In S. R. Aragon (Ed.). Beyond access: Methods and models for increasing retention and learning among minority students, (pp. 55-62). New Directions for Community Colleges, No. 112. San Francisco: Jossey Bass.

Tinto, V. (1975). Dropout from higher education: A theoretical synthesis of recent research. Review of Educational Research, 45 (1), 89-125.

Woolbright, C. (1989). Valuing diversity on campus: A multicultural approach. Bloomington, IN: Association of College Unions International.

Myron L. Pope is an assistant professor of adult and higher education in the Department of Educational Leadership and Policy Studies at the University of Oklahoma in Norman, Oklahoma. myronp@ou.edu 